\title{
SIRKULASI SINEMA DALAM RENTAL VCD/DVD DI YOGYAKARTA
}

\author{
Irham Nur Anshari \\ Departemen Ilmu Komunikasi, Universitas Gadjah Mada \\ irham.nur.anshari@ugm.ac.id
}

\begin{abstract}
Abstrak: Sirkulasi Sinema atau peredaran produk audio visual (seperti film dan serial televisi) dalam keping VCD/DVD merupakan praktik masif yang pernah ditemui di rental VCD/DVD pada dekade 90-an dan awal 2000-an di Yogyakarta. Perkembangan teknologi yang cepat pada satu dekade terakhir melahirkan kultur akses media yang baru di era digital, seperti praktik streaming dan download film/video. Akses online ini tidak hanya masif melalui platform-platform legal, tetapi juga platform ilegal seperti situssitus bajakan, serta sirkulasi film melalui warung internet (warnet) di Yogyakarta. Perkembangan ini meninggalkan kultur sirkulasi sinema melalui keping VCD/DVD yang berimplikasi pada matinya industri/bisnis rental VCD/DVD. Menggunakan metode penelitian kualitatif, riset ini mencatat jejak praktik sirkulasi sinema dalam rental VCD/DVD di Yogyakarta, sebagai cara membaca akar budaya perkembangan pembajakan dan sirkulasi media di era digital. Riset ini menemukan bagaimana praktik sirkulasi sinema dalam rental VCD/DVD menunjukkan kultur pembajakan digital dan sirkulasi sinema yang masif di Yogyakarta telah berlangsung sejak tiga dekade silam.
\end{abstract}

Kata kunci: Sinema, Sirkulasi Film, Rental, VCD/DVD, Yogyakarta

\begin{abstract}
The circulation of audio-visual products (such as films and television series) on VCD/DVDs is a massive practice that has been encountered in VCD/DVD rentals in the 90s and early 2000s in Yogyakarta. The rapid development of technology in the last decade gave birth to a new media access culture in the digital era, such as the practice of streaming and downloading movies/videos. This online access is not only massive through legal platforms but also illegal platforms such as pirated sites, as well as film circulation through internet cafes (warnet) in Yogyakarta. This development left the culture of cinema circulation through VCD/DVDs, which had implications for the demise of the VCD/DVD rental industry/business. This research records traces of the practice of cinema circulation in VCD/DVD rentals in Yogyakarta as a way of reading the cultural roots of the development of piracy and media circulation in the digital era. This research found how the practice of cinema circulation in VCD/DVD rental shows that the culture of digital piracy and massive cinema circulation in Yogyakarta has been going on for three decades.
\end{abstract}

Keywords: Film circulation, Rental, VCD/DVDs, Yogyakarta

\section{Pendahuluan}

Menyusuri sebuah jalan utama di Kota Yogyakarta, yaitu Jalan Kaliurang, saat ini tak lagi dapat ditemui jajaran-jajaran rental VCD/DVD. Setidaknya sampai satu dekade lalu, tahun 2010, masih dapat ditemui beberapa rental VCD/DVD di jalan tersebut.
Dalam pengamatan awal penelitian ini, tidak hanya di jalan tersebut, jajaran rental VCD/DVD kini nyaris tak dapat ditemui lagi di Kota Yogyakarta secara umum. Padahal, rental VCD/DVD sempat menjadi bisnis yang marak memenuhi Kota Yogyakarta setidaknya hingga tahun 2010. 
Asumsi yang dapat diajukan terkait "punahnya" bisnis ini salah satunya ialah teknologi VCD/DVD yang tergantikan oleh teknologi mengakses media baru (baik itu film, musik, game, atau software komputer) yang telah beralih ke teknologi online. Tawaran menonton film atau mendengarkan lagu secara streaming misalnya telah menjadi praktik sehari-hari, sebagai implikasi dari konsumsi internet yang semakin masif dibanding satu dekade silam (Anshari 2019). Selain akses secara streaming atau download, sirkulasi media di Yogyakarta misalnya juga dapat ditemui melalui warung internet (warnet), sebuah situs yang menawarkan sirkulasi secara lebih efisien dalam segi biaya dan teknologi (lihat Anshari, 2016; Wibowo, 2020; Juliastuti, 2019).

Sebagai sebuah situs sirkulasi sinema yang pernah masif mendatangkan konsumen, menjadi penting untuk mencatat peran rental VCD/DVD, khususnya di Kota Yogyakarta. Satu hal penting dari peran rental VCD/DVD ini yaitu bagaimana situs tersebut mensirkulasikan produk tontonan sinema (film atau serial televisi) bajakan. Konten bajakan dalam hal ini mengacu baik pada konten yang diduplikasikan secara ilegal, ataupun konten yang memang tidak disirkulasikan melalui jalur resmi atau formal (bioskop, televisi, atau jual-beli VCD/DVD original). Terkait hal tersebut, peran rental VCD/DVD tidak hanya terletak di aspek ekonomis (konteks industri di mana sinema sebagai komoditas), tetapi juga aspek kultural, yakni konteks di mana sinema dilihat sebagai konten yang mengandung ideologi dan dikontrol sirkulasinya.

Tulisan ini berangkat dari pertanyaan dasar bagaimana peran rental VCD/DVD dalam aspek ekonomis maupun kultural, khususnya terkait sirkulasi sinema (film dan serial televisi) di Yogyakarta. Menggunakan metode penelitian kualitatif, tulisan ini dibangun dari data wawancara dengan pendekatan historis yang berusaha menggali pengalaman dari beberapa subjek terkait pengalamannya sebagai konsumen ataupun pekerja di rental VCD/DVD di Yogyakarta dalam rentang waktu sejak pertengahan dekade 1990-an hingga akhir dekade 2000an. Berangkat dari pertanyaan dasar di atas, tulisan ini ingin mengelaborasi konteks yang lebih luas, terkait bagaimana peran rental VCD/DVD dalam perkembangan sirkulasi sinema di konteks global.

Tulisan ini akan dibagi ke dalam beberapa bagian. Tiga bagian selanjutnya akan memaparkan kerangka pemikiran riset ini. Yang pertama mengenai pemahaman dasar pada sirkulasi media baru, sebuah sirkulasi di era digital ini yang memiliki bentuk sangat berbeda dengan sirkulasi atau distribusi di era analog. Bagian berikutnya mencoba mengelaborasi kasus-kasus sirkulasi sinema di luar bioskop, termasuk sirkulasi informal yang kerap dilabeli ilegal sebagai praktik pembajakan. Bagian ketiga lebih spesifik, mengeksplorasi dinamika rental VCD/DVD di Yogyakarta. Bagian metodologi akan menguraikan detil metode serta subjek dalam riset ini. Bagian selanjutnya berupa temuan dan analisis yang akan ditutup dengan kesimpulan dan saran.

\section{Sirkulasi Media Baru}

Mendefinisikan media baru sama rumitnya dengan memahami praktik empiris perkembangan teknologi media yang begerak cepat dan tersebar. Setidaknya term media baru telah diperkenalkan oleh seorang ilmuwan komunikasi ternama, Marshal McLuhan pada tahun 1950-an. McLuhan mengasosiasikan media baru sebagai karakteristik teknis dari media, seperti pengumpulan informasi secara elektronik dan jangkauannya yang global, yang merupakan hal langka saat itu (McLuhan, 1953).

Tulisan ini mencoba mensimplifikasikan term "media baru" dengan memilih definisi sederhana dari Lev Manovich bahwa seluruh objek media baru, 
baik yang dibuat dengan komputer maupun dikonversi dari media analog terdiri dari kode digital (Manovich, 2002). Merujuk pada definisi tersebut, "lingkup media baru" (new mediascape) digunakan dalam tulisan ini sebagai konteks di mana produksi, distribusi, dan konsumsi media berbasis pada teknologi komputer, data digital, dan juga jejaring internet. Lingkup media baru berkembang sangat dinamis sehingga batasannya hanya akan terlihat jelas jika kita merujuk pada lingkup media analog. Sebagai ilustrasi, sejarah film berbasis pita seluloid dapat dikategorikan berada di luar lingkup media baru.

Dinamika media baru ini membawa persebaran media dalam suatu konsep yang oleh Henry Jenkins dkk. (2013) dalam bukunya Spreadable Media disebut sebagai "sirkulasi'. Seperti halnya "distribusi", sirkulasi merupakan "proses" di antara produksi dan konsumsi. Namun berbeda dengan distribusi yang bersifat top down dan umumnya komersil, sirkulasi merujuk pada penyebaran konten media baik yang top down maupun bottom up serta komersil maupun grassroots. Pergeseran dari distribusi ke sirkulasi memberikan sinyal sebuah gerakan menuju budaya yang lebih partisipatif di mana publik bukanlah sekedar konsumen tetapi juga merupakan pihak yang membentuk, membagi, membingkai, atau me-remix konten media dengan cara-cara yang tidak pernah diimajinas ikan sebelumnya (Jenkins dkk., 2013: 2).

Sirkulasi konten ini tidak bisa dipungkiri terkait erat dengan perkembangan teknologi media. Perangkat komunikasi online terus berkembang memfasilitasi praktik sirkulasi yang informal dan makin instan. Platform-platform ini bukan hanya menawarkan pengguna untuk membagi konten, tapi juga mendapatkan pendapatan alternatif dari aktivitasnya. Meski demikian, Jenkins dkk. menolak asumsi bahwa infrastruktur teknologi media merupakan aspek primer dalam dinamika sirkulasi ini. Jenkins dkk. (2013: 63) menggarisbawahi poin penting bahwa sebagian besar dari kita yang tumbuh dalam ekonomi kapitalis memahami praktik membeli dan menjual barang. Meski demikian, kita juga tumbuh dalam tatanan sosial lain yang menuntut adanya sikap saling berbagi. Dalam logika komoditas, berbagi data dapat dilihat merusak secara ekonomi; sementara dalam logika sosial, tidak saling berbagi justru merusak tatanan sosial. Berdasar paparan di atas, tulisan ini bermaksud meninjau praktik sirkulasi sinema di rental VCD/DVD dengan kerangka yang terkait erat dengan teknologi media serta konteks sosial \& budaya para partisipan.

\section{Sirkulasi Sinema di Luar Bioskop}

Perkembangan teknologi yang memungkinkan film tidak lagi hanya ditonton di layar lebar gedung bioskop telah menjadi fenomena yang menarik minat para peneliti. Barbara Klinger (2006) dalam bukunya Beyond the Multiplex mendiskusikan praktik menonton film melalui home theater, VHS, DVD, televisi kabel, dan internet). Menggunakan istilah new media aristocrats sebagai konteks lingkup risetnya, Klinger mencatat bagaimana sejak tahun 1990-an home theater telah menjadi tren eksebisi di mana audiens mendesain ruangan menonton beserta perangkat televisi dan audio yang canggih untuk menonton film (Klinger, 2006: 17-53). Meskipun televisi melalui siarannya telah lama menjadi salah satu bentuk eksebisi film di luar bioskop, kemunculan tren home theater secara tegas menunjukkan adanya pergeseran praktik menonton film sebagai aktivitas komunal ke personal.

Dalam salah satu bagian khusus, Klinger (2006: 54-90) juga membahas perkembangan praktik mengoleksi film 
seiring kemunculan teknologi VHS, laser disc, hingga DVD. Dalam hal ini, pengkoleksian film menciptakan pergeseran praktik menonton sebagai praktik yang temporal (hanya bisa ditonton secara sekali di bioskop, kecuali membayar ulang untuk menonton ulang) dan linear (dari awal hingga selesai secara langsung). Ketika film diakses di perangkat personal seperti DVD player, film dapat ditonton kapanpun dan berkalikali sesuai kehendak sang kolektor. Film dalam bentuk ini juga dapat di-pause ataupun di-rewind sesuai dengan kehendak penonton.

$$
\text { Perkembangan internet }
$$

memungkinkan sirkulasi film yang semakin sederhana, cepat, dan bebas biaya. Michael Strangelove (2015: 48-73) mendiskusikan pembajakan televisi dan film dengan menyebut adanya dua bentuk: download dan streaming. Kedua meteode ini menggunakan sistem P2P seperti BitTorrent. Mendownload atau mengunduh sebuah film membutuhkan waktu menunggu meskipun film kemudian menjadi dimiliki sehingga bisa diakses di waktu lain, sementara streaming cenderung hanya membutuhkan waktu untuk menunggu film dimulai tetapi penonton tidak menyimpan film tersebut. Menariknya, Strangelove mencatat bagaimana kemunculan platform streaming legal seperti Hulu dan Netflix menurunkan angka pembajakan. Ini menunjukkan bahwa kemudahan akses menjadi faktor penting bagi audiens film dalam lingkup media baru di samping faktor ekonomi.

$$
\text { Meskipun internet telah }
$$

memungkinkan persebaran konten secara cepat, bebas biaya, dan lintas batasan geografis, penting mengingat bahwa tidak seluruh lapisan masyarakat mendapatkan akses internet dengan kualitas yang baik. Hal inilah kemudian yang menjadi poin penting untuk mencurigai tetap bertahannya praktik berbagi data secara offline. Praktik ini umumnya disebut sebagai "sneakernet" yang merujuk pada praktik transfer data elektronik dengan memindahkan secara fisik perangkat penyimpan data seperti flashdisk atau harddisk ekternal dari satu komputer ke komputer lain alih-alih menggunakan koneksi internet (techopedia, n.d.).

Salah satu bentuk dari Senakernet misalnya apa yang bisa ditemui di Kuba dengan istilah "El Paquete Semanal" (Paket Mingguan). Sebagai warga yang negaranya membatasi akses koneksi internet, El Paquete Semanal menjadi contoh praktik penyebaran konten secara offline. Ia berupa satu terabyte data terkini yang terdiri dari musik, film Hollywood, serial TV, aplikasi telpon pintar, majalah eletronik, dan sebagainya. Setiap minggu, para kurator yang tidak teridentifikasi menyeleksi konten dan mengirimkannya melalui sebuah jaringan kompleks yang terdiri dari ratusan distributor yang mengirimkan perangkat dari pintu ke pintu (Pedro, 2015).

Praktik mengopi film di warnet Yogyakarta misalnya, dapat dikatakan sebagai salah satu bentuk Sneakernet yang menjadi alternatif dari tarif internet yang masih di atas standar ekonomi para pengguna. Meskipun mengopi di warnet tidak gratis, setidaknya cara ini lebih hemat dan praktis ketimbang mengunduh ataupun streaming film yang juga memakan waktu lebih lama. Penting dicatat bahwa tawaran film dalam warnet juga ditemui di negara lain, tidak hanya di Indonesia. Di Cina misalnya, dibicarakan bagaimana warnetwarnet seolah telah berubah menjadi bioskop mini karena menawarkan banyak film untuk ditonton. Pada tahun 2010, China Film Copyright Association (CFCA) membuat kebijakan agar warnet membayar iuran per bulan karena telah menjadi tempat memutar film-film China (Xueqing, 2012). 
Di belahan dunia lain, di Selandia Baru, diberitakan bagaimana Kepolisian setempat merazia warnet-warnet yang diduga menawarkan film bajakan dalam jumlah yang besar. Seiring meningkatnya akses internet di rumah-rumah, warnet di Australia berjuang mencari cara untuk menarik konsumen. Beberapa warnet mencoba menambahkan jasa dengan memenuhi server mereka dengan film dan musik yang diperoleh secara ilegal dari internet, menawarkan konsumen akses "all-you-can-eat" dengan bayaran yang murah (Moses, 2013). Berdasar paparan di atas, penting kemudian untuk melihat praktik sirkulasi sinema di luar bioskop ini berakar sejak maraknya sirkulasi via keping VCD/DVD.

\section{Rental VCD/DVD di Yogyakarta}

Pada tahun 2013, redaktur Kinology

website Cinema Poetica, Windu Jusuf (2014), mewawancarai Bambang Adrianto, pemilik rental VCD/DVD film Universal Entertainment. Wawancara tersebut merupakan bagian dari proyek penulisan sejarah rental film di Yogyakarta. Bagian ini akan mengutip beberapa poin dari wawancara tersebut guna menambah pemahaman pada konteks rental VCD/DVD di Yogyakarta.

Dalam wawancara tersebut, Bambang bercerita bahwa perjumpaannya dengan dunia sinema di Yogyakarta telah dimulai pada tahun 1993. Rental terbesar di tahuntahun itu Laser 2000 di Jalan Kaliurang. Ia dengar dari penjaganya malah sudah berdiri dari tahun 1990. Pada jaman itu sebagian besar koleksinya VHS dan Betamax. Tapi rental paling tua seingatnya bernama Tara Indah. Itu adalah rental pertama yang menyewakan Laser Disc. VCD lebih murah dan praktis. Tapi masalahnya waktu itu, player masih mahal. Bisnis rental semakin lama semakin mirip wartel. Ini bisnis instan, orang punya modal, menyewakan film-film mereka, jumlahnya tambah banyak, dan setelah itu gulung tikar. Seleksi alam, kualitas, pelayanan akhirnya lebih menentukan. Di tahun-tahun itu, belum ada CD/DVD-RW. Kalaupun ada, harganya masih mahal. Dulu Bambang jarang kopi film, apalagi download. Kapasitas harddisk juga masih kecil.

Universal Entertainment pertama kali buka tanggal 22 Februari 2000. Film-film alternatif (art house) ada di Universal sejak 2004. Saat pertama kali buka sebetulnya Universal sudah berkeinginan mengkoleksi film-film itu. Tapi dulu belum tahu bagaimana dapatnya. Yang ia tahu, film ini diputar di mana, dapat penghargaan apa, dan seterusnya. Info itu diperoleh dari internet. Dan, sayangnya, tidak semuanya masuk ke Yogyakarta. Dulu kapasitas internet masih terbatas. Untuk dapat film-film itu Bambang harus barter atau cari ke Jakarta.

Terkait jenis keping VCD/DVD, Bambang menceritakan bahwa sebelumnya, film-film yang dipinjamkan berupa master (keping DVD/VCD asli) semua, sama seperti rental franchise macam VideoEzy. Tapi di Yogyakarta, sistem ini kemudian berubah dengan sistem menggandakan master. Menurut Bambang, tidak hanya Universal yang melakukan kopi-mengkopi semacam itu. Jaman keemasan VCD dulu, setiap rental biasanya beli lima keping untuk satu judul film. Harga satunya saja Rp 50 ribu. Di Universal saat itu, ketika setiap film dipinjamkan ke pelanggan, pihak rental takut hilang atau rusak. Padahal sewanya Rp 3000 per judul tidak sebanding dengan ongkos beli master-nya.

Asosiasi Rekaman Film dan Video Indonesia (ASIREFI) pernah minta supaya rental jangan mengkopi. Bambang mengakui ia pun sebenarnya tidak ingin mengkopi karena repot, harus beli $C D$ blank, harus bakar, buang waktu, dan seterusnya. Tapi kalau harga VCD semahal itu, cuma bisa berapa kali kita sewakan film-film itu? 
Belum kalau dicuri. Rental-rental franchise itu bisa pakai sistem seperti itu karena modalnya besar, ratusan juta. Nah, sementara rental-rental lain yang modalnya cuma berapa puluh juta nggak bisa begitu. Mereka jawab, "Kami beli lisensinya mahal." Bambang pernah diberitahu kalau film-film yang beredar di Indonesia itu dibeli dengan dua cara. Cara waktu dan kuantitas. Cara waktu misalnya begini: distributor beli lisensi satu judul untuk jangka waktu tertentu, dan selama itu ia bisa mengkopi dalam jumlah yang tidak dibatasi. Cara kuantitas lain lagi: tidak ada batasan waktu, tapi dibatasi jumlah kopiannya. Misalnya 10 ribu keping. Nanti kalau mau ditambah harus lapor lagi.

Terkait kultur konsumen, Bambang menuturkan bahwa beberapa pelanggan awalnya mencari film-film porno di Universal. Tapi ia tidak pernah menyewakan film jenis tersebut. Ia khawatir dengan image rental dan ingin supaya rental tidak dipandang sebelah mata, seolah-olah rental film sama dengan rental film porno. Menurut Bambang, sejak orang ramai mengunduh film porno lewat internet, image rental berubah, karena film porno lebih gampang didapat lewat internet. Polisi kemudian lebih sering razia warnet ketimbang rental.

Bambang juga menceritakan soal situasi di rental. Universal buka dari jam sepuluh pagi sampai dua belas malam. Ada dua shift jaga. Shift pertama dari jam 10.0018.00, shift II kedua dari jam 18.00-24.00. Masing-masing orang harus dapat sepuluh shift pagi dan sore secara bergantian. Kerjanya dibagi dua tim. Satu jaga rental, satu lagi-yang Bambang kerjakanmenyiapkan film, bikin cover DVD, dan sebagainya. Upah karyawan disesuaikan dengan UMR. Tidak ada tunjangan, tapi ada THR. Dan kalau mereka sakit, akan dibackup sedikit-sedikit.

Berkembangnya sirkulasi sinema di warnet memberikan dampak pada bisnis Universal. Tahun 2010-2011, Universal nyaris ambruk. Seperti yang dituturkan Bambang:

"Ya sekarang logikanya begini aja: kamu pilih download atau bayar $\mathrm{Rp}$ 3000? Sorry ya, orang Indonesia kan latah. Satu download semua download. Tapi yang jelas, banyak pengunjung lama kembali ke rental. Banyak juga sih pengunjung baru. Kembali ke prinsip awal: konsumer Jogja ingin produk yang murah, bisa diperoleh dengan cepat, dan bagus. Mungkin lewat download, kamu bisa dapat film bagus. Tapi pertanyaannya: murah nggak? Cepat nggak?"

\section{Metode Penelitian}

Penelitian ini akan menggunakan paradigma konstruktivis atau interpretatif. Paradigma interpretatif digunakan dalam penelitian ini sesuai tujuan untuk memahami bagaimana informan di dalam kondisi mereka sehari-hari memaknai dan menginterpretasi praktik/peristiwa di dalam kehidupan mereka (Wimmer \& Dominick, 2010). Peneliti dalam paradigma ini berperan sebagai fasilitator atau "penyambung lidah" dari berbagai pandangan yang mampu merekonstruksi pemahaman awal peneliti maupun partisipan. Dengan pendekatan metode penelitian kualitatif yang konstruktivis, peneliti berusaha menggali berbagai perspektif mengenai topik yang diteliti.

Teknik pengumpulan data yang dilakukan terdiri dari: wawancara (kelompok maupun individu) dan pengumpulan dokumen. Adapun observasi lapangan yang direncanakan tidak berhasil dilakukan karena situs rental VCD/DVD yang akan diobservasi ketika dikunjungi oleh peneliti dalam kondisi tutup. Kondisi ini diasumsikan karena terdampak adanya pandemi. Pengambilan data dalam penelitian ini akan dilakukan di Yogyakarta selama bulan Juli dan Agustus 2020. 
Pencarian data diawali dengan desk studies untuk memahami riset terkini mengenai sirkulasi sinema dan pembajakan digital. Wawancara dilakukan dengan menemui informan-informan untuk memahami lebih dalam pengalaman empiris serta observasi konteks sosial politik sebagai tambahan panduan dalam menganalisis. Dalam penelitian ini peneliti mewawancarai empat informan dari berbagai latar belakang (konsumen dan penjaga rental VCD/DVD. Dengan pertimbangan etis, tulisan ini tidak mencantumkan nama sebenarnya para informan. Dua informan diwawancarai secara berkelompok, dua informan lain diwawancarai secara individu. Masingmasing wawancara berlangsung sekitar 1-2 jam. Data dalam penelitian ini diolah melalui tahapan pemetaan, pendalaman dinamika melalui perspekif informan, dan dipaparkan di bagian temuan data. Temuan data dalam hal ini disajikan dengan pembagian pada sub. Pertama, terkait sirkulasi sinema sebelum kemunculan VCD, yakni dalam format VHS, Betamax dan Laserdisc. Kedua, berfokus pada keping VCD. Dan terakhir, membahas perihal dinamika rental VCD/DVD. Data selanjutnya dianalisis dengan mempertimbangkan kerangka pemikiran sebagai alat analisis.

\section{Temuan Data}

Sirkulasi Sinema dalam VHS, Betamax, dan Laserdisc

Sebelum tahun 1990-an, pembajakan sudah dapat ditemui dalam sirkulasi film melalui media video, khususnya VHS dan Betamax. Peredaran video sendiri sebenarnya diatur dalam sistem klasifikasi yang dibagi dalam penanda tiga warna: merah, biru, dan hijau. Video merah untuk penonton usia 17 tahun ke atas, video warna biru untuk 13 tahun ke atas, dan video warna hijau untuk segala umur. Sebelum tahun 1990-an tersebut, sirkulasi sinema telah identik dengan pembajakan. Pembajakan atau penggandaan video lebih masif dilakukan perorangan, tidak untuk disewakan tetapi untuk dinikmati sendiri atau dipinjamkan ke orang sekitar.

Di Yogyakarta saat itu terdapat beberapa rental kaset video: Elok, Borobudur, dan Mbarek. Sebelumnya, sekitar pertengahan 1980-an, juga marak persewaan video keliling. Konsumen dalam hal ini akan memesan satu minggu sebelumnya untuk kemudian dibawa oleh penyewa keliling yang datang door to door.

Laserdisc merupakan media film digital lain yang muncul di akhir 1980-an dan awal 1990-an. Bedannya dengan VHS atau Betamax, Laserdisc dapat dikatakan sebagai media yang lebih mewah. Biaya menyewa satu keping Laserdisc bisa mencapai 5-10 ribu (bahan bakar minyak saat itu sekitar 300 rupiah per liter) untuk jangka waktu tiga hari. Bandingkan dengan biaya penyewaan video yang jauh lebih murah sekitar 1000 rupiah untuk jangka waktu seminggu. Tidak semua orang mempunyai player kaset Laserdisc sehingga penyewaan biasanya satu paket dengan player. Harga ini setimpal dengan kualitas gambar Laserdisc yang bagus, berbeda dengan kualitas VHS/ Betamax yang terkadang bisa lebih jelek dari kualitas gambar televisi lantaran telah disewa 10-20 orang sebelumnya.

Salah satu jenis konten Laserdisc yang populer adalah film semi porno. Jenis film ini pada tahun 1990-an sangat digemari. Film-film ini kemungkinan besar diedarkan secara ilegal langsung didistribusikan impor dari luar negeri. Konsumen umumnya menyewa film semi porno ini bukan sebagai konsumsi pribadi, tetapi untuk ditonton bersama teman-teman. Menyewanya dilakukan secara urunan bersama-sama mengingat biayanya yang mahal. Untuk film full porno sendiri sebenarnya juga dapat ditemui di rental Laserdisc tersebut, tetapi 
perederan secara terbuka hanya untuk pelanggan tertentu.

Pada tahun 1990-an, sirkulasi film juga dapat ditemui dalam ruang-ruang bioskop mini yang disewakan. Model ini perlu diperiksa kembali aspek legalitasnya. Di kota lain misalnya, bioskop mini ini menjadi alternatif dari bioskop yang lebih teruntuk kelas menengah atas. Penonton umumnya datang untuk menonton film-film populer baik lokal maupun luar yang telah dijadwalkan oleh operator bioskop mini. Seperti halnya bioskop komersil pada umumnya, penonton dapat melihat jadwal ditempel di dinding bioskop mini.

Dalam sirkulasi sinema melalui Laserdisc, dapat ditemukan juga film-film cult atau film-film klasik seperti Star Wars. Film-film ini termasuk laku disewa mengingat nyaris tidak adanya cara alternatif mengakses film-film ini selain televisi. Konsumen Laserdisc pada dasarnya merupakan kelompok kelas menengah atas yang ingin mendapatkan kepuasan tertinggi dalam menonton film secara kualitas gambar yang tidak dapat ditemui di televisi. Di bioskop, film-film hollywood yang termasuk film-film baru sebenarnya juga muncul. Hanya memang penonton saat itu kurang informasi sehingga tidak mengetahui berapa banyak film-film box office yang baru.

Selain dari media massa, informasi mengenai film-film baru justru dapat diketahui dari kualitas gambar yang ada di video. Film-film baru umumnya ditemukan dalam kualitas gambar yang goyang karena direkam langsung di bioskop. Terkadang suaranya hanya dari sisi kiri (tidak stereo). Di Yogyakarta sendiri, saat itu terdapat beberapa bioskop, seperti Regent dan Empire. Sebelum jaringan bioskop 21 masuk, film diputar di bioskop dengan jadwal yang tidak tertentu. Jejaring bioskop 21 membawa kultur jadwal film yang update sesuai peredaran film box office Hollywood.
Sirkulasi Film dalam Keping VCD

Pada tahap awal sirkulasi film melalui VCD, sudah dapat ditemui adanya sirkulasi informal atau pembajakan digital. VCD bajakan umumnya merupakan salinan dari VCD original sehingga kualitasnya cukup bagus. VCD bajakan ini lebih banyak dijual daripada disewakan. Hal ini disebabkan lantaran salinan ini pada pertengahan tahun 1990-an bukan merupakan suatu hal yang umum ditemui mengingat biaya $\mathrm{CD}$ writer (alat yang digunakan untuk menyalin konten VCD) terbilang sangat mahal.

Salah satu rental penyewaan VCD yang muncul dan populer di Yogyakarta adalah Disc House, yang terletak di kawasan jembatan merah, Jalan Gejayan. Biaya peminjaman saat itu sekitar 3000 hingga 5000 rupiah. Meski kualitas video saat itu tidak terlalu bagus, konsumen dapat merasakan excitement yang berbeda karena bisa menonton film baru yang sedang menjadi box office global. Popularitas VCD ini bisa jadi merupakan faktor penyebab matinya popularitas bioskop kelas menengah saat itu. Meskipun popularitas televisi mungkin bisa dikatakan menjadi faktor determinan pengalihan penonton saat itu. Sebagai perbandingan harga, biaya menonton bioskop tidak begitu jauh dibanding biaya menyewa VCD. Perbedaannya, biaya menonton sekitar 6000 atau 7000 rupiah hanya bisa dinikmati satu orang. Sedangkan biaya yang lebih murah sedikit dapat digunakan untuk menyewa VCD yang dapat ditonton satu keluarga atau mahasiswa satu kost.

Untuk VCD film baru, sudah dapat dipastikan film tersebut merupakan film dengan kualitas bajakan. Hal ini terkait adanya kontrak tertentu seperti tidak mendistribusikan film dalam media VCD sebelum enam bulan sejak film diputar di bioskop. Dalam perkembangannya, muncul rental film yang khusus untuk VCD original. 
Salah satunya Video Ezy yang sudah terlisensi izin internasional. Permasalahannya, beberapa rental kecil yang sarat bajakan tidak terkontrol. Mentari Disc salah satunya, memiliki tiga kios. Dalam jenisnya, ia mempunyai dua tipe VCD bajakan yang biasa disebut copy ori (salinan VCD original) dan non-ori yang (VCD dengan kualitas bajakan).

Sehubungan dengan peredaran VCD bajakan yang sifatnya informal, sangat berdampak positif dan negatif terhadap aliran ekonomi. Mentari Disc sebagai contoh, memang mentargetkan pada konsumen mahasiswa yang dapat dikatakan bagian konsumen kelas menengah bawah. Seorang penjaga Mentari Disc bercerita bahwa tiap bulan ia harus membayar ke pihak tertentu lantaran bisnis "ilegal" rental ini. Biaya yang dibayarkan per bulan sekitar 5 juta rupiah. Bisa dibayangkan berapa besar keuntungan rental tersebut di luar biaya tersebut. Untuk jumlah pegawainya sekitar 8 orang yang dibagi ke dalam dua shift.

Mentari Disc dapat dikatakan merupakan rental kecil. Rental besar lain yang dikenal saat itu selain Disc House adalah Wahana. Selain itu, terdapat banyak rental kecil yang menjamur. Dalam radius 300 meter, kira-kira dapat ditemui 10 buah rental. Dalam beberapa rental kecil, konsumen hanya dapat mendapati film ditawarkan dengan jumlah terbatas. Salah satu yang mereka jual adalah film porno. Hal ini bisa jadi merupakan salah satu aspek yang menunjang tinggi ekonomi rental tersebut.

Salah satu rental populer, Istana, dikenal membuka akses film porno ke penonton mulai pukul 21.00. Pada pukul 9 malam tersebut, album-album sampul film porno tersebut ditawarkan dengan keterangan kategorinya (Asia, Barat, Semi, Full, dll). Jumlah albumnya bisa mencapai 20 buah dengan masing-masing album berisi sampul banyak film. Rental ini biasanya buka hingga pukul 12 malam. Film-film porno ini hanya dapat disewa siang hari jika cukup kenal dengan penjaga rental.

\section{Sinema dalam Rental VCD/DVD}

Wahana adalah salah satu rental VCD/DVD yang populer di Yogyakarta. Wahana memiliki tiga cabang. Dua rental terletak di Jalan Kaliurang, sebuah kawasan padat mahasiswa yang dekat dengan Universitas Gadjah Mada. Cabang lain di kawasan Jalan Moses yang juga merupakan area kampus di Gejayan. Mayoritas penjaga rental Wahana adalah mahasiswa dengan kisaran 8 sampai 13 pegawai. Sistem penjagaan menggunakan sistem shift kerja part time. Gaji tiap bulan sekitar 300 ribu rupiah. Dalam praktiknya terdapat sistem bonus sesuai target pemasukan. Untuk shift pagi target omset sebesar 350 ribu rupiah per hari. Sedangkan untuk shift siang target omset sebesar 500 ribu rupiah per hari. Pada saat masa mahasiswa aktif (bukan masa libur kuliah), gaji yang diterima bisa mencapai 1 juta rupiah.

Pemiliki rental Wahana adalah pecinta film. Rental tersebut didirikan karena memang pemilik hobi menonton film. Pada perkembangannya rental dibagi ke dalam dua divisi, rental film dan rental software komputer. Dapat dikatakan bahwa Wahana menyewakan film bajakan. Meski demikian, ada jenis film yang merupakan copy dari VCD original. Copy ini lantaran kualitasya sama dengan original sehingga biasa disebut ori. Wahana termasuk rental yang tidak menyewakan konten film porno. Biasanya konsumen yang hendak menyewa konten film porno, diarahkan ke rental lain seperti Istana. Untuk biaya sewa, satu film dalam format VCD sebesar 2500 rupiah. Dengan sistem kejar target omset, pemasukan rental sehari bisa mencapai 1 juta hingga 1,5 juta rupiah. Omset umumnya lebih banyak pada divisi rental software ketimbang film.

Untuk supplay film, umumnya format bajakan yang datang lebih dulu setelah film 
tayang di bioskop. VCD bajakan ini memiliki kualitas gambar yang buruk lantaran hasil rekaman kamera di bioskop. Jika sudah ada rilis VCD original di pasaran, pihak pemilik akan membuat salinan VCD original tersebut. Selanjutnya copy VCD tersebut akan didistribusikan oleh supervisor ke rental per sepuluh keping sesuai dengan tingginya minat permintaan. Penjaga rental akan memberikan data terkait permintaan film. CD copy film yang datang dalam bentuk keping VCD kosong. Penjaga bertugas menempel sticker keterangan judul film dalam keping tersebut.

Sehubungan penjaga dituntut untuk dapat menaikkan permintaan di rental, penjaga juga terkadang turut aktif membaca resensi dan informasi dari film-film populer yang beredar. Rental Wahana juga menyediakan majalah film sebagai bahan referensi. Berbeda dengan rental lain, di Wahana tidak disediakan televisi bagi konsumen untuk mengecek konten film. Wahana tidak menerapkan batasan maksimal film yang dipinjam dalam satu hari. Umumnya satu konsumen meminjam lebih dari satu judul film, bahkan ada yang mencapai puluhan film sekali pinjam. Waktu pinjam di Wahana selama tiga malam dua hari. Meski demikian, terkadang penjaga memberikan fleksibilitas waktu pinjam jika konsumen meminjam banyak film.

Setiap konsumen meninggalkan KTP atau SIM sebagai jaminan peminjaman. Meski demikian, sebenarnya rental tidak begitu rugi jika konsumen tidak mengembalikan VCD yang dipinjam. Hal ini lantaran rental bisa memiliki bahkan sampai seratus copy judul film jika film tersebut laris. Jika film tidak begitu laris, copy film tersebut dibuang.

Pada saat masa kejayaan rental Wahana (sekitar tahun 2004 hingga 2006) dapat dikatakan tidak terdapat bioskop komersil yang bagus di Yogyakarta. Hal inilah yang mungkin menjadi faktor penting tingginya angka konsumen rental VCD/DVD. Selain film bioskop, serial televisi juga menjadi konten yang ditawarkan rental. Saat itu serial televisi drama Korea Selatan sudah mulai mendapat perhatian konsumen. Serial televisi lain yang misalnya serial Jepang dan Amerika. Wahana tidak meneyediakan konten-konten film yang sifatnya lebih art house. Biasanya untuk film art house, penjaga akan menyarankan konsumen untuk menyewa di rental lain, seperti Sketsa.

Jenis film dalam format DVD berbeda dengan format VCD. Format ini mulai populer tahun 2005. DVD sendiri memiliki berbagai level kualitas, misalnya DVD 9. Meski dapat dikatakan bajakan, penyewaaan DVD lebih bersifat eksklusif. Pada saat itu DVD player belum menjadi alat yang banyak dimiliki. Biaya sewa satu keping DVD sebesar 3000 ribu rupiah. Untuk peminjam DVD, terdapat denda yang besar jika merusak DVD. Biaya denda ini bisa mencapai 10 kali lipat, 30 ribu rupiah.

\section{Pembahasan}

Riset ini membaca praktik yang muncul pada rental VCD/DVD di Yogyakarta. Ada setidaknya tiga kata kunci yang digunakan untuk membedah praktik tersebut. Pertama, adalah pembajakan digital. Perspektif ini menekankan pada sifat sirkulasi media baru digital yang menawarkan kemungkinan duplikasi yang mudah sehingga muncullah praktik yang kerap dilabeli sebagai pembajakan. Pembajakan digital umumnya dikontraskan dengan praktik akses ekonomi formal yang menguntungkan produsen secara legal. Sementara pembajakan digital umumnya memangkas aliran ekonomi dengan mengalirkan keuntungan/ profit pada pihak distributor media. Dalam riset ini, praktik rental VCD/DVD tidak dimaknai sematamata sebagai pembajakan digital yang ilegal. Namun, mengutip Karaganis (ed., 2011), 
pembajakan memainkan peranan penting dalam berbagai konteks. Oleh karena itu, praktik sosial yang muncul bersama pembajakan digital perlu menjadi perhatian.

Penelitian ini menemukan bahwa salah satu jenis konten yang populer dalam pembajakan digital adalah film porno/ semi porno. Jenis film ini pada tahun 1990-an sangat digemari dalam perederan informal. Hal ini bisa dimaklumkan mengingat nyaris tidak ada perederan konten seperti ini secara formal di Indonesia, bahkan hingga kini. Pada masa di mana internet belum hadir dengan berbagai tawaran konten-konten pornografi, rental menjadi salah satu saluran yang memungkinkan. Film-film ini kemungkinan besar diedarkan secara ilegal langsung didistribusikan impor dari luar negeri. Konsumen umumnya menyewa film semi porno ini bukan sebagai konsumsi pribadi, tetapi untuk ditonton bersama temanteman. Menyewanya dilakukan secara urunan bersama-sama mengingat biayanya yang mahal. Untuk film full porno sendiri sebenarnya juga dapat ditemui di rental Laserdisc atau VCD/DVD tersebut, tetapi perederan secara terbuka hanya untuk pelanggan tertentu.

Apa yang bisa disimak dari fenomena ini adalah bagaimana pembajakan digital memungkinkan adanya keterbukaan konten/ ideologi dari luar yang mentransformasi sebuah kultur sosial. Pembajakan digital dapat dikatakan membuat perkembangan pengetahuan/ ideologi suatu kelompok sosial semakin sulit diatur secara formal dan legal. Pornografi bisa jadi hanyalah salah satu bentuk konten/ ideologi yang mudah diidentifikasi. Sementara di sisi lain, berbagai konten global dengan ideologinya yang beragam larut tersikulasi dalam praktik pembajakan digital ini.

Perspektif kedua yang dipakai adalah konsep yang terkait erat dengan konsep pembajakan digital di atas, yaitu sirkulasi sinema. Berbeda dengan sistem distribusi yang bersifat top-down, sirkulasi bersifat lebih cair. Ketika media digital rilis di pasaran, teknologi memungkinkan adanya duplikasi sehingga penyebaran menjadi tidak mudah terkontrol. Pergeseran dari distribusi ke sirkulasi memberikan sinyal sebuah gerakan menuju budaya yang lebih partisipatif di mana publik bukanlah sekedar konsumen tetapi juga merupakan pihak yang membentuk, membagi, membingkai, atau me-remix konten media dengan cara-cara yang tidak pernah diimajinasikan sebelumnya (Jenkins dkk., 2013: 2).

Dalam praktik yang ditemukan di rental VCD/DVD, rental beserta pemilik dan penjaganya merupakan aktor yang memungkinkan sirkulasi terjadi. Seperti dipaparkan dalam temuan data di atas, adanya CD-writer memungkinkan pemilik rental untuk menduplikasi sebuah film dalam format VCD menjadi puluhan bahkan ratusan dalam waktu singkat. Penjaga rental turut berperan untuk melabeli keping VCD. Di satu sisi, rental merupakan perpanjangan tangan dari agen distributor VCD bajakan yang sebelumnya telah merekam gambar film dengan kamera di bioskop. Jejaring sirkulasi ini melibatkan orang banyak dan cukup sulit untuk diidentifikas i.

Perspektif ketiga yang tidak kalah penting dalam meneropong studi ini adalah fokus pada industri sirkulasi film. Jika bioskop lebih umum dipandang sebagai saluran eksebisi film, kemampuan konsumen untuk menonton film melalui media digital personal membuat skema distribusi/ sirkulasi dapat dimainkan pihak-pihak lain, seperti rental ataupun warnet. Tak bisa dipungkiri, faktor ekonomi menjadi alasan mendasar bagaimana praktik pembajakan digital dalam sirkulasi film ini berkembang biak dalam rental VCD/DVD di Yogyakarta. Seperti diungkapkan dalam temuan data di atas, pada masa jayanya bisnis rental VCD/DVD, dapat ditemukan 10 buah rental dalam radius 300 
meter, khususnya di area mahasiswa yang menjadi target konsumen utama.

Perkiraan besarnya industri dapat ditinjau dari adanya target omset per hari. Menggunakan studi pada rental Wahana, salah satu rental yang besar dan populer, shift pagi memiliki target omset sebesar 350 ribu rupiah, sementara shift siang memiliki target sebesar 500 ribu rupiah. Dengan sistem kejar target omset, pemasukan rental sehari bisa mencapai 1 juta hingga 1,5 juta rupiah. Ketika muncul perkembangan medium DVD, terdapat biaya yang berbeda lantaran sifat DVD yang dikemas sebagai medium yang lebih eksklusif. Denda pengembalian DVD yang telat misalnya mencapai $10 \mathrm{kali}$ lipat biaya sewa. Meski terlihat besarnya pemasukan yang didapat oleh rental, perlu dicatat bahwa sifat bisnis yang ilegal ini turut melahirkan praktik pengeluaran uang yang ilegal. Seorang penjaga rental kecil misalnya bercerita bahwa tiap bulan ia harus membayar ke pihak tertentu lantaran bisnis "ilegal" rental VCD ini. Biaya yang dibayarkan per bulan dapat mencapai kisaran 5 juta rupiah.

\section{Simpulan dan Saran}

Sebagai sebuah situs sirkulasi media yang pernah masif mendatangkan konsumen, menjadi penting untuk mencatat peran rental VCD/DVD, khususnya di Kota Yogyakarta. Satu hal penting dari peran rental VCD/DVD ini yaitu bagaimana situs tersebut mensirkulasikan produk tontonan sinema (film atau serial televisi) bajakan. Konten bajakan dalam hal ini mengacu baik pada konten yang diduplikasikan secara ilegal, ataupun konten yang memang tidak disirkulasikan melalui jalur resmi atau formal (bioskop, televisi, atau jual-beli VCD/DVD original). Terkait hal tersebut, peran rental VCD/DVD tidak hanya terletak di aspek ekonomis (konteks industri di mana sinema sebagai komoditas), tetapi juga aspek kultural, konteks di mana sinema dilihat sebagai konten yang mengandung ideologi dan dikontrol sirkulasinya.

Dengan pendekatan metode penelitian kualitatif, penelitian ini menggali berbagai perspektif mengenai topik yang diteliti. Secara umum peneliti bertindak sebagai fasilitator dari para informan. Teknik pengumpulan data yang dilakukan terdiri dari: wawancara (kelompok maupun individu) dan pengumpulan dokumen. Pengambilan data dalam penelitian ini akan dilakukan di salah satu kota besar Indonesia sesuai rencana penelitian yaitu Yogyakarta selama bulan Juli dan Agustus 2020. Pencarian data diawali dengan desk studies untuk memahami riset terkini mengenai sirkulasi film dan pembajakan digital. Wawancara dilakukan dengan menemui informan-informan untuk memahami lebih dalam pengalaman empiris serta observasi konteks sosial politik sebagai tambahan panduan dalam menganalisis. Dalam penelitian ini peneliti mewawancarai empat informan dari berbagai latar belakang.

Riset ini membaca praktik yang muncul pada rental VCD/DVD di Yogyakarta. Ada setidaknya tiga kata kunci yang digunakan untuk membedah praktik tersebut. Pertama, adalah pembajakan digital. Perspektif kedua yang dipakai adalah konsep yang terkait erat dengan konsep pembajakan digital di atas, yaitu sirkulasi film. Perspektif ketiga yang tidak kalah penting dalam meneropong studi ini adalah fokus pada industri sirkulasi film.

Penelitian ini menyimpulkan beberapa hal berdasar analisis tiga perspektif di atas terhadap temuan data. Apa yang bisa disimak dari fenomena ini adalah bagaimana pembajakan digital memungkinkan adanya keterbukaan konten/ ideologi dari luar yang mentransformasi sebuah kultur sosial. Pembajakan digital dapat dikatakan membuat perkembangan pengetahuan/ideologi suatu kelompok sosial semakin sulit diatur secara formal dan legal. Pornografi bisa jadi 
hanyalah salah satu bentuk konten/ideologi yang mudah diidentifikasi. Sementara di sisi lain, berbagai konten global dengan ideologinya yang beragam larut tersikulasi dalam praktik pembajakan digital ini.

Dalam praktik yang ditemukan di rental VCD/DVD, rental beserta pemilik dan penjaganya merupakan aktor yang memungkinkan sirkulasi terjadi. Seperti dipaparkan dalam temuan data di atas, adanya CD-writer memungkinkan pemilik rental untuk menduplikasi sebuah film dalam format VCD menjadi puluhan bahkan ratusan dalam waktu singkat. Penjaga rental turut berperan untuk melabeli keping VCD. Di satu sisi, rental merupakan perpanjangan tangan dari agen distributor VCD bajakan yang sebelumnya telah merekam gambar film dengan kamera di bioskop. Jejaring sirkulasi ini melibatkan orang banyak dan cukup sulit untuk diidentifikasi.

Tak bisa dipungkiri, faktor ekonomi menjadi alasan mendasar bagaimana praktik pembajakan digital dalam sirkulasi film ini berkembang biak dalam rental VCD/DVD di Yogyakarta. Seperti diungkapkan dalam temuan data di atas, pada masa jayanya bisnis rental VCD/DVD, dapat ditemukan 10 buah rental dalam radius 300 meter, khususnya di area mahasiswa yang menjadi target konsumen utama. Meski terlihat besarnya pemasukan yang didapat oleh rental, perlu dicatat bahwa sifat bisnis yang ilegal ini turut melahirkan praktik pengeluaran uang yang ilegal.

Penelitian ini dapat dikatakan sebagai penelitian yang singkat dan minim. Data yang diperoleh dalam penelitian ini bersifat sangat terbatas dan memerlukan triangulasi data lebih lanjut. Sebagai studi kualitatif, beberapa situs rental yang dibahas tidak dapat dianggap merepresentasikan rental di Yogyakarta secara umum. Guna melengkapi pemahaman pada sirkulasi sinema kontemporer, tulisan ini perlu dilanjutkan dengan studi-studi sirkulasi sinema di era digital. Meski demikian, temuan data dalam penelitian ini diharapkan memberi sumbangsih pada pengetahuan historis praktik pembajakan digital serta industri dan sirkulasi sinema di Indonesia, khususnya di Yogyakarta.

\section{Daftar Pustaka}

Anshari, Irham Nur. (2016). Memahami Pembajakan Digital dalam Budaya Mengopi Video di Warnet. Channel Jurnal Komunikasi Vol 4, No. 2. Yogyakarta: Prodi Ilmu Komunikasi UAD.

Anshari, Irham Nur. (2019). Sirkulasi Film dan Program Televisi di era Digital: Studi Kasus Praktik Download dan Streaming melalui Situs Bajakan. Komuniti: Jurnal Komunikasi dan Teknologi Informasi 10 (2), 88-102.

Jenkins, Henry, Sam Ford, \& Joshua Green. (2013). Spreadable Media. New York \& London; New York University Press.

Juliastuti, Nuraini (2018). Limits of sharing and materialization of support: Indonesian Net Label Union. InterAsia Cultural Studies, 19:1, 87-102.

Jusuf, Windu. (2014). Sebelum Kamu Kenal Hiroshima Mon Amour, Pasti Kamu Pernah Suka American Ninja Kan? https://cinemapoetica.com/sebelumkamu-kenal-hiroshima-mon-amourpasti-kamu-pernah-suka-americanninja-kan/

Karaganis, Joe. (Ed.) (2011). Media Piracy in Emerging Economies. New York: Social Science Research Council.

Klinger, Barbara. (2006). Beyond the Multiplex. Los Angeles: University of California Press.

Manovich, Lev. (2002). What is New Media? dalam Hassan \& Thomas (ed.) The New Media Theory Reader. Open University Press.

McLuhan, Marshall. (1953). The Later Innis. Queen's Quarterly 60. 
Moses, Asher. (2013). Internet Cafes Clean Out after Raid. http://www.smh.com.au/news/technol ogy/internet-cafes-clean-outafterraid/2008/01/17/1200419959751. html 17 Januari 2013.

Pedro, Emilio San. (2015). Cuban Internet Delivered Weekly by Hand. http://www.bbc.com/news/technology3381665510 Agustus 2017.

Strangelove, Michael. (2015). Post-TV. Toronto: University Toronto Press.

Sneakernet. (n.d.). Techopedia. https://www.techopedia.com/definitio $\mathrm{n} / 1880 /$ sneakernet.

Wibowo, Tangguh Okta dkk. (2020). Understanding New Consumption Sites of Internet Cafe in Yogyakarta, Indonesia. JSP, 23:3.

Xueqing, Jiang. (2012). Internet Movie Fans Fear Twist in the Tale. http://www.chinadaily.com.cn/china/2 010-11/18/content_11566608.htm 18 November 2012. 